IJMS 2018 vol. 5 (1): 83 - 90

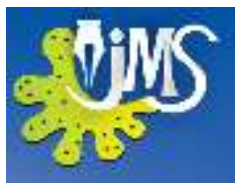

\title{
Can we predict movie Revenue?
}

\author{
Ratnayake MP \\ University of Visual and Performing Arts, Colombo, Sri Lanka
}

\begin{abstract}
The movie industry is characterized with its unpredictability in success and failure. Predicting revenue of a particular movie has intrigued industry tycoons as well as scholar as a challenging problem. The cinema acts not only as a expressive artistic medium, but also serves as large scale industry that impact on the economy However some foreign scholars revealed that there are methodologies to forecast future revenue of the movies. Film revenue forecasting has been studied in variety of contexts ranging form easthetics economics, management to statistic and psychology. In this study author examines whether movie revenue can be predicted by using determinants like criticism, budget, propaganda directors creativity, star power and copies released to theaters. All the films screened in 2012 were selected, and collected data related to them. The number of copies released to theaters, propaganda expenditures and budgets were collected. Star power of 2012 film actors and actresses, were converted into mathematical figures. Also a scholarly panel was appointed to give grades to those stars and resultant figures were used for final calculating. Same process was used when calculating directors creativity. To calculate propaganda expenditure, financial figures as well as other scenarios like Contar deals, free interviews were used. sing regression model author founds that there is a correlation between revenue and those six determinants. In conclusion it can be said that using these determinants, movie revenue can be predicted. However this study only test six determinants, and there are some important determinants to be tested. The results can be further improved by incorporating more determinants and larger sample size in future studies.
\end{abstract}

KEYWORDS - Movie, Revenue, Criticism, Budget, Propaganda

Corresponding author: M.P. Ratnayake, Email: vidu@unl.upali.lk 


\section{INTRODUCTION}

William Goldman, two time Academy award winner for best screenplay, says that nobody can predict box office success of a movie prior to screening (Goldman, 1983) former President of Motion picture Association of America, claims that, not until the films opens in darkened theater, no one can predict what will happen to its revenue (Valenti, 1978) According to Goldman (1983) forecasts of expected values have zero precision. Goldman, (1983) believes that, movies are creative products and play out their lives on screens in unique ways that no one even the creator cannot predict their outcomes.

Although some argue that it impossible to predict revenue of a film, there are arguments to the contrary.

Investing in film industry is still considered to be a high risk business for producers distributors and exhibitions. This high risk situation has provoked many scholars to attempt the challenging task of predicting movie revenue. Accurate predicting benefits the entire chain of movie making, from better planning to proper marketing.

However, predicting revenue of a particular movie has intrigued industry tycoons as well as scholars as a challenging problem the cinema not only as a expressive artistic medium, but also serves as a large scale industry that impact on the economy. Film industry comprises the commercial and artistic institutes of film making, ie. film studios, media, production companies directors actors and other film crew.

Movie making is a risky business and while sometimes investment in a blockbuster movie pays off, other times it does not. According to
Gunter (2018), discovering the formula to movie success is the Holy Grail of movie producers. Film revenue forecasting has been studied in variety of contexts ranging from aesthetics, economics, management to statistic and psychology.

Modeling movie income has long been of interest to movie makers and marketing scholars, and there are many foreign researches done to cover that realm. The aims of such researches was to identify the predictors of a movies revenue. Some studies have investigated the effect of these predictors on opening weekend's revenue. Others concern about the total revenue.

Up to eleven predictors have been introduced by the researchers. They are as follows. The movies star power (Smith \& Smith, 1986 : Sochay 1994) Release date (Litman, 1983; Sharda \& Delen, 2006) Film critics (Litman, 1983 ; Elberse \& Eliasheberg, 2003) Film's MPAA ratings (Ravid, 1999 ; Walls, 2005)

Awards and nominations received by the movie (Litman \& Kohl, 1989; Sochay, 1994) No of screen or theaters in which film plays ( Wallace, Seigrman \& Holbrook, 1993) Budget (Litman \& Kohl 1989, ) The Distributor (Litman , 1983) Whether or not the films is Sequel (Litman \& Kohl, 1989) Film's genre (Litman, 1983)

Early trailer (Yi,. Ling Eileen and Wen, 2013)

Some studies try to identify the effect of quantitative factors only, others concern about both the quantitative and qualitative aspects. Quantitative factors like budgets and number of copies release to cinema halls are easy to find out. But in the case of qualitative factors it is different. Movies are experience goods and thus movie fans have to rely on quality signals provided by movies themselves. Most probably 
these quality signals guide consumer's choices. Quality signals like star power, director's creativity, awards genre, critical reviews attract consumers. Although reviews and awards categorize here comes under the qualitative signals, they can be calculated and categorized as quantitative as well. But the qualitative signals like star power or director creativity is difficult to calculate, some researches evade that difficulties bu using ImDb classification .

In this study we examined the question of predicting movie revenue. Our study focuses on how factors like criticism, budget, propaganda, Director's creativity star power and number of copies released to theaters affect movie revenue. However we found tremendous difficulties in converting qualitative signals to quantitative values as many of Sri Lankan directors and starts do not have ImdB values. Therefore we have to use alternative methods. When giving marks to stars we consider not only the ImdB value but also stars previous records, specially income records and awards or nominations. When deciding director's creativity we follow the same procedure. Here we follows what Elberse (2007) and De Vany and Walls (1999) have done in calculating star power.

\section{SURVEY OF THE LITERATURE}

Litman (1983) was the first scholar to construct a model to predict the movie revenue. Independent variables of his study were movie genre , cost , MPAA ratings, Star power, Academy awards, release date and Distributor.

Litman and Kohl (1989) replicated and expanded the basic work done by Litman (1983),
Terry, Butler and De Armond(2007), examined the determinants of revenue in the motion picture industry using a sample of 505 films. Regression results of De Armond indicated that primary determinants of box office revenue are Awards, sequels, critic reviews, MPAA ratings, cost and release exposure. The study concluded that ten present increase in critical approval earns extra seven million dollars and academy award nomination earns six million dollars.

The results of the study of Elberse (2007) strongly indicated that stars impact revenue and that some stars contributed more to revenue than others. Smith and Smith (1986), suggested that power of award impact on revenue.

Eliasberg and Sawhney (1994), have created a model of movie going experience to predict moviegoer's enjoyment level before watching movie. But this model was constructed and tested only in laboratory.

Austin (1983) studied the impact of MPAA ratings on movie revenue and concluded that there is no correlation between these two variables. Simonoff and Sparrow (2000), concluded that box office performance of movies can be predicted with some accuracy using available information. Sharda and Delen (2006), introduced new neural network model to predict box office success.

Higher movie ratings for frightening scenes and scary music were related to much enhanced box office performance. Cerridwen and Simonton (2009), sampled 914 movies that released form from 2001 to 2005 in North America. They analyzed, how movie ingredients like including sex, frightening scene and scary music impact revenue. Study of Cerridwen and Simonton 
(2009) proves that the higher a movie's sex nudity score the more poorly it performed at box office.

Study of Kim, Hong and Kang (2017), confirmed that Word Of Mouth has a stronger influence on total box office forecasting .

Hennig - Thurau et. al., (2006) also provides a revenue predicting model for the UK film market.

\section{METHODOLOGY}

We selected year 2012 and collected data for all the films screened that year and the criticisms published related to them. Then number of copies released to theaters, propaganda expenditures and budgets were collected. Following Elberse (2007) and De vanny and Walls (1999), we converted star power of 2012 film actors and actresses into mathematical figures. Other than considering previous record we also appoint a scholarly panel to give grades to those stars. Resultant figures were used for final calculating. We followed same process, when calculating directors creativity. When calculating propaganda expenditure, not only the financial figures concerned but also the other scenarios like Contra deals, free interviews and ect. Were also used.

Revenues of those films were obtained via Film Corporation. Below chart exhibits the details of the six variables.

The empirical model employed to test the determinants of revenue for our study is specified below as.

Revenue $=\beta+\alpha_{1} \mathrm{Cr}+\alpha_{2} \mathrm{Di}+\alpha_{3} \mathrm{St}+\alpha_{4} \mathrm{No}+$ $\alpha_{5} \mathrm{Bu}+\alpha_{6} \mathrm{Ad}$
Where Revenue is total revenue, $\mathrm{Cr}$ is the resultant reviews published in all print media and internet. $\mathrm{Di}$ is figures given to Director Creativity. St is Star power. No means Number of copies. $\mathrm{Bu}$ represents Budget and $\mathrm{Ad}$ represents total propaganda using $\mathrm{R}$ calculators we calculate coefficients for all six determinants.

We used $\mathrm{R}$ calculators and calculated coefficient values and $\mathrm{P}$ values. Coefficient values related to the calculation are given below.

\section{RESULTS AND DISCUSSION}

To test the goodness of our model we calculated the R squared and Adjusted R squared value.

Multiple regression model we employed gives $\mathrm{R}$ squared value of 0.876 and adjusted $\mathrm{r}$ squared value 0.793 . It says that this model can predict the revenue up to the percentage of seventy nine approximately.

In statistics $\mathrm{R}$ squared is the proportion of the variance in the dependent variable that is predictable from the independent variables and normally symbolized by R2

$\mathrm{R}$ squared value ranges from zero to one and is stated as a percentage. When the value of $\mathrm{R}$ squared is equal to one or $100 \%$, if means that every actions of dependent variable are completely explained by movements up independent variable.

$\mathrm{R}$ squared measures the strength of model usually, the lager the $\mathrm{R}$ squared, the better the regression model, fits the observation. However, there are some limitations of $\mathrm{R}$ 
squared. In regression, R2 is increasing with increase in the number of regression in the model and create errors. Then we calculated the Adjusted R squared also. Adjusted R squared measures the proportion of variation explained by only those independent variables that really assist in explaining the dependent variable. Adjusted $\mathrm{R}$ squared increase only when independent variable is significant and affects dependent variable.

Coefficient values of six determinations are as follows:

Reviews (criticism) 6.017 Director Power-148. Star power 18.39 No of hall -.375 Budget 0.635 Advertisement 13.29

These coefficient values reveal how each determinants impact to the revenue. According to this results only the star power criticism and advertisement impact significantly.

We separately calculated Pearson correlation coefficient value for criticism only. In that process the value for Pearson correlation, we got was 0.025749. Approximately it was 0.026 and that value was very weak.

According to Evans (1996) this weak value exhibit the poor correlation between two variables, here Revenue and the Criticism. However when we sued regression model (using six determinants) impact of the Criticism, was significant.

The most significant contributor to movie revenue was found to be the star power.

This study confirms that Sri Lankan moviegoers consider the stars of the film, before going to the theater, but not the directors, studies of Kimetal (2016) Smith and Smith (1986) and
Ghiassi geo (2015) confirm that star power impact positively to movie revenue. This result will help film producers to plan their managing systems.

However our result of the budget was inconsistent with three studies (Litman, 1983: Ravid, 1999 and Terry etal 2005) that say budget correlate revenue. Only one study showed that relationship was insignificant (De Vany \& Walls 1999)

\section{CONCLUSION}

We conclude that using some determinants, movie revenue can be predicted. However we only test six determinants, and there are some important determinants we were unable to test. If we had data of word of mouth and release date we would be able to calculate more higher level accuracy. The sample we used here also is a very small one and that creates error. 


\section{M.P.Ratnayake}

\begin{tabular}{|l|c|c|c|c|c|c|}
\hline Film names & Director & $\begin{array}{c}\text { Star } \\
\text { power }\end{array}$ & Halls & Budget & propaganda & crit \\
\hline sakvithi & 1 & 4 & 21 & 9 & 1 & 0 \\
\hline matha & 5 & 5 & 37 & 30 & 5 & 2 \\
\hline kusapaba & 9 & 9 & 51 & 100 & 10 & 7 \\
\hline Vassane s & 1 & 4 & 14 & 5 & 1 & 2 \\
\hline kurumittek & 1 & 3 & 15 & 3 & 1 & 0 \\
\hline vijaya kuweni & 6 & 7 & 46 & 25 & 8 & 6 \\
\hline super six & 4 & 6 & 44 & 90 & 8 & -5 \\
\hline heena dige & 3 & 5 & 17 & 7 & 3 & -2 \\
\hline daruwane & 3 & 5 & 43 & 7 & 6 & 5 \\
\hline colour & 4 & 5 & 20 & 10 & 3 & 7 \\
\hline senasuru maruwa & 4 & 5 & 40 & 19 & 4 & 2 \\
\hline karma & 8 & 4 & 22 & 26 & 4 & 17 \\
\hline prathiru & 4 & 6 & 40 & 22 & 4 & 1 \\
\hline mouse & 2 & 4 & 30 & 10 & 4 & -1 \\
\hline iniyawan & 9 & 1 & 26 & 17 & 4 & 22 \\
\hline jeevithe lassanai & 3 & 6 & 50 & 8 & 8 & -1 \\
\hline
\end{tabular}

Chart 1

\begin{tabular}{|c|c|c|c|c|c|c|}
\hline \multicolumn{7}{|c|}{ Model Summary } \\
\hline \multirow[t]{2}{*}{ Model } & \multirow[t]{2}{*}{$\mathbf{R}$} & \multirow[t]{2}{*}{ R Square } & \multirow{2}{*}{$\begin{array}{l}\text { Adjusted R } \\
\text { Square } \\
\end{array}$} & \multirow{2}{*}{$\begin{array}{c}\text { Std. Error of the } \\
\text { Estimate }\end{array}$} & & \\
\hline & & & & & R Square Change & F Change \\
\hline 1 & $936^{\mathrm{a}}$ & 876 & .793 & 25,156 & 876 & 10.568 \\
\hline \multicolumn{7}{|c|}{ a. Predictors: (Constant), crit, ad, bud, star, nos, direct } \\
\hline \multicolumn{7}{|c|}{ b. Dependent Variable: revenue } \\
\hline
\end{tabular}

\begin{tabular}{|c|c|c|c|c|c|c|}
\hline \multicolumn{7}{|c|}{ ANOVA: } \\
\hline \multicolumn{2}{|c|}{ Model } & Sum of Squares & df & Mean Square & $\mathrm{F}$ & Sig. \\
\hline \multirow[t]{3}{*}{1} & Regression & 40123.783 & 6) & 6687.297 & 10.568 & $.001^{2}$ \\
\hline & Residual & 5695.217 & 9 & 632.802 & & \\
\hline & Total & 45819.000 & 15 & & & \\
\hline \multicolumn{7}{|c|}{ a. Dependent Variable: revenue } \\
\hline
\end{tabular}

\begin{tabular}{|c|c|c|c|c|c|c|c|}
\hline & bud & .001 & .018 & .006 & .014 & , & .001 \\
\hline & ad & .000 & .014 & .001 & .000 & co1 & \\
\hline & crit & 462 & .000 & .085 & 316 & 459 & .478 \\
\hline \multirow[t]{7}{*}{$\mathrm{v}$} & revenue & 16 & 16 & 16 & 16 & 16 & 16 \\
\hline & direc: & 16 & 16 & 16 & 16 & 16 & 16 \\
\hline & star & 16 & 16 & 16 & 16 & 16 & 16 \\
\hline & nos & 16 & 16 & 16 & 16 & 16. & 16 \\
\hline & bud & 16 & 16 & 16 & 16 & 16 & 16 \\
\hline & ad & 16 & 16 & 16 & 16 & 16 & 16 \\
\hline & crit & 16 & 16 & 16 & 16 & 16 & 16 \\
\hline
\end{tabular}




\section{REFERENCE}

AUSTIN B. The Influence Of MPAA's rating system on motion picture attendance, paper presented at A. M. of the Eastern speech communication, Ocean City MD Ap. 1980; 24.26.

AUSTIN B. Critics and Consumers, Journal of Popular Films and Television. 1983; (10) 4 pp 157-168.

BASUROY S. CHATERGEE S \& RAVID A. How Critical Are Critical Reviews -Journal of Marketing (69). 2003; pp 103-118.

BOATWRIGHT P. BASUROY S \& KAMAKURA W. Reviewing the Reviewers", Quantitative Marketing and Economics 5(4). 2007; pp 418-420

CERRIDWEN A. \& SIMONATON DK. Sex does not sell, Psychology of Aesthetics 3(4). 2009; 200-210 PP

DE VANY A \& WALLS WD 1999. Undertraining in the movie Industry. Journal of Cultural Economics 23. 1999; PP 285-318

DORTCH C. Going to Movies American Demographics 184 -7. 1996; pp 2223

DUAN W. GU B. \& WHINSTON A. Do online Review Matter. Decision Support System vol.4. 2008; pp 1007-1016

ELBERSE A. Power of Stars Do Star Actors Drive the successor movies Journal of Marketing, Oct, No. 4. 2007; 102-120 pp
ELIASHBERG J. \& SHUGAN SM Film Critics Influencers or Predictors?, Journal of Marketing 61(2) April. 1997; pp 68-78

EVANS, J.D. Straightforward Statics for the behavioral Sciences. Film Corporation report 2012. 1996; 24(3) pp 69-71

GOLDMAN W. Adventures in the screen and trade Warner brothers New York. 1983.

GUNTER B Predicting Movie success at box office - Cham McMillion. 2018.

JEON J \& JIAOL. The Influence effect of critic's Reviews, Honor Thesis submitted to Duke University. 2012.

KIM T. HONG J \& KANG P. Box Office forecasting considering competitive environment and Word of Mouth in Social Network - Computational Intelligence and Neuroscience. 2017.

LEVENE C. Marketing Art Films to College Students - working paper Wharton School of Pennsylvania. 1992. pp. 1-14

LITMAN B. Predicting Success of Theoretical Movies Journal of popular culture, 16,spring. 1983; pp 158-175

LITMAN B. \& KOHL A. Predicting Financial Success of Motion Pictures experience. The 80', The Journal of Media Economics 2(1). 1989; 35-50 pp 
MIDDLETON A. BARGIN E. MORLEY K. \& PARKER M. (2014) Using films to engage participants and then gather attitudes Socia Science Research vol 4 march ; 2014; p211-243

PLUCKER J. KAUFMAN J. TEMPLE J. \& QIAN M. Psychology and Marketing vol.1.26(5) May. 2009; pp 470-498.

SMITH S \& SMITH K. Successful movies applied economics 18. 1986; pp501

REINSTEIN DA \& SNYDER CM. The Influence of Expert Reviews on Consumer Goods. The Journal of Industrial Economics (53)1. 2005; pp 29-51

SOCHAY S. Predicting the performance of motion picture the journal of media economics 7.4. 1994; pp20
SHANDA R \& DELEN D. Predicting Box Office success of motion pictures with neural network. 2006.

SIMONOFF JS \& SPARROW I. Predicting movie Groos. Chance 13(3). 2000; 15-24 pp

TERRY BUTLER MN \& DE ARMOND D. The Determinants of domestic box officer performance in the motion picture industry. South-western Economics Review, . 2005; 137148

WYATT R. \& BADGER D. How Review Affect Film Interest and Evaluation Journalism and Mass Communication Quarterly. 1984; pp 74-878

YI'.W HO. E LIM L \& WEN J. The effect of trailer thesis submitted to university of TUNKU ABDUL RAHMAN Expert System with applications. 2013; 243-254 pp 